\title{
Tectonic control of the Tejo river fluvial incision during the late Cenozoic, in Ródão - central Portugal (Atlantic Iberian border)
}

\author{
P. Proença Cunha ${ }^{\mathrm{a}, *}$, A. Antunes Martins ${ }^{\mathrm{b}}$, S. Daveau ${ }^{\mathrm{c}}$, P.F. Friend ${ }^{\mathrm{d}}$ \\ a Departamento de Ciências da Terra, Universidade de Coimbra, Largo Marquês de Pombal, 3000-272 Coimbra, Portugal \\ ${ }^{\mathrm{b}}$ Departamento de Geociências da Universidade de Évora, Rua Romão Ramalho, 59, 7002-554 Évora, Portugal \\ ${ }^{\mathrm{c}}$ Centro de Estudos Geográficos da Universidade de Lisboa, Alameda da Universidade, 1600-214 Lisboa, Portugal \\ ${ }^{\mathrm{d}}$ Department of Earth Sciences, University of Cambridge, Downing Street, Cambridge CB2 3EQ, United Kingdom
}

Received 5 January 2004; received in revised form 7 May 2004; accepted 13 July 2004

Available online 18 September 2004

\begin{abstract}
Staircases of strath terraces and strongly incised valleys are the most typical landscape features of Portuguese rivers. This paper examines the incision achieved during the late Cenozoic in an area crossed by the Tejo river between the border with Spain and the small town of Gavião. In the more upstream reach of this area, the Tejo crosses the Ródão tectonic depression, where four levels of terraces are distinguished. During the late Cenozoic fluvial incision stage, the Ródão depression underwent less uplift than the adjacent areas along the river. This is reflected by the greater thicknesses and spatial extent of the terraces; terrace genesis was promoted by impoundment of alluvium behind a quartzitic ridge and the local presence of a soft substratum. Outside this tectonic depression, the Tejo has a narrow valley incised in the Hercynian basement, with some straight reaches that probably correspond to NE-SW and NNW-SSE faults, the terraces being nearly absent. Geomorphological evidence of tectonic displacements affecting the Ródão dissected terrace remnants is described. Geochronological dating of the two younger and lower terrace levels of this depression suggests a time-averaged incision rate for the Tejo in the Ródão area, of ca. $1.0 \mathrm{~m} / \mathrm{ka}$ over the last 60 thousand years. A clear discrepancy exists between this rate and the $0.1 \mathrm{~m} / \mathrm{ka}$ estimated for the longer period since the end of the Pliocene. Although episodes of valley incision may be conditioned by climate and base-level changes, they may also have been controlled by local factors such as movement of small fault-bounded blocks, lithology and structure. Regional crustal uplift is considered to be the main control of the episodes of valley incision identified for this large, long-lived river. A model is proposed in which successive regional uplift events - tectonic phases - essentially determined the long periods of rapid river downcutting that were punctuated by short periods of lateral erosion and later by some aggradation, producing strath terraces. (C) 2004 Elsevier B.V. All rights reserved.
\end{abstract}

Keywords: Tejo river; Cenozoic; Incision; Terraces; Tectonic uplift; Portugal

* Corresponding author.

E-mail addresses: pcunha@dct.uc.pt (P.P. Cunha),aam@uevora.pt (A. Antunes Martins), sdaveau@clix.pt (S. Daveau), pff1000@esc.cam.ac.uk (P.F. Friend). 